\title{
ABSOLUTE PROPERTIES OF ARBITRATION DECISION IN BUSINESS DISPUTE SETTLEMENT BASED ON LAW NO. 30 OF 1999 ON ARBITRATION AND ALTERNATIVE DISPUTE RESOLUTION LAW BASED ON JUSTICE THEORY PERSPECTIVE
}

\author{
Aryani Witasari \\ Lecturer of Law Faculty in Sultan Agung Islamic Univrsity \\ aryani@unissula.ac.id
}

\begin{abstract}
Legal disputes in the business world do not just appear, but it arises from a discrepancy between one party with another party who is bound by a legal relationship directly or indirectly. Direct legal relationship can be in the form of business cooperation. Article 2 of Law Number 30 Year 1999 concerning Arbitration and Alternative Dispute Settlement indicates that dispute settlement or disagreement among parties in a certain legal relationship shall be the authority of the arbitration institution, if it has been agreed in an arbitration agreement. The authority of the arbitration institution in resolving the dispute is reinforced by the provisions of Article 3 of Law Number 30 Year 1999 on Arbitration and Alternative Dispute Settlement. According to Lawrence Meir Friedman the success or failure of law enforcement depends on: Substance Law, Legal Structure/ Legal Institution and Legal Culture. The disadvantages of the exercise of the arbitration authority's authority over the absolute nature of the arbitral decision in the settlement of the business are currently in the substance, structure and legal framework, so there is an amendment to Law no 30 of 1999 on Arbitration and Alternative Dispute Resolution. This final and legally binding arbitral decision, if associated with Aristotle's corrective theory of justice, does not at all reflect the basic value of justice. This is indicated by not giving an opportunity for another party whose position is higher to correct the decision, whereas in the judicial system, the court as an ordinary court having legal status (legal statue) and legal authority (legal authority/legal power). Verdict the panel of judges can still be corrected through the usual remedies (appeals) and extraordinary reviews.
\end{abstract}

Keywords: Arbitration, authority, verdict, justice

\section{A. INTRODUCTION}

The development of national law in order to create a just and prosperous society based on Pancasila and the 1945 Constitution of the State of the Republic of Indonesia is directed at the realization of a national legal system, which is done with the formation of a new law. Specifically, the legal products are needed to support the development of the national economy.

Legal disputes in the business world do not just appear, but arise from a discrepancy between one party with another party who is bound by a legal relationship directly or indirectly. Direct legal relationship can be in the form of business cooperation. Business cooperation in practice is carried out through a cooperation contract which is poured in its formal form, namely the cooperation contract agreement in all its forms. Cooperation agreements made by business actors are not bound in any particular form, but they are free both its content and form as long as it is agreed upon by the parties that bind. Since the legal system of the treaty embraces an open system, ie the parties may enter into any agreement even though it has not been regulated in the Civil Code. This is known as the principle of freedom of contract, as it appears in Article 1338 (1) that it seems to make a statement that the parties are permitted to enter into any agreement and that it will bind the parties as binding the Act. The limitation of freedom is only what is called Public Order and Decency. ${ }^{1}$

The emergence of conflicts or disputes in the business world greatly affects the business

Subekti, Aneka Perjanjian, (Bandung : Alumni Bandung, 2004), page 3 
continuity of the business actors involved in the conflict or dispute, so that the parties will seek to resolve the dispute. A general dispute resolution process can be made by the parties through two channels, namely litigation through a public court/commercial court or through an alternative dispute resolution route based on good faith to the exclusion of a litigation settlement in court.

One of the process of settling disputes through an out-of-court line, namely arbitration institution. Agreements to settle disputes through arbitration bodies are commonly set forth in previously agreed agreements, so that in the event of a dispute/conflict, the process of settlement automatically based on the contents of the agreement is through the arbitration body.

The process of dispute settlement through arbitration institution has advantages compared to settlement through litigation, because in the arbitration institution there is no possible appeal against arbitration institution's decision. This provides an advantage in the settlement of disputes, namely the short turnaround time and the final and binding nature of the verdict. This is stipulated in the provisions of Article 60 of Law Number 30 Year 1999 on Arbitration and Alternative Dispute Settlement.

The absolute nature of the decision of the arbitration institution, in terms of legal certainty, is capable of providing legal certainty for the parties to the dispute because of its final and binding nature. However, in terms of the principle of justice has not provided a sense of justice for either party. The Arbitrator/Arbitral Ruling basically has no absolute truth, so that it may be possible to contain mistakes in the decision of the arbitration. In such condition, of course there is one party who feel aggrieved over the arbitration decision, so that when viewed from the basic value of justice there should be a legal effort to uphold justice.

In fact, Law Number 30 Year 1999 on Arbitration and Alternative Dispute Settlement has closed the possibility for parties who are not satisfied with the decision of the arbitration institution.

In accordance with the provisions of Article 60 of Law Number 30 Year 1999 concerning Arbitration and Alternative Dispute Settlement above, the decision of the arbitration institution already has a binding legal force (incraht van gewijsde). It is also stipulated in the elucidation of Article 60 of Law Number 30 Year 1999 concerning Arbitration and Alternative Dispute Settlement that arbitral decision is final and therefore cannot be submitted an appeal, cassation or review. The provision seems to affirm the authority of the arbitrator in deciding a case such as the Supreme Court Justice in the Supreme Court, whose verdict is final and binding.

The arbitral decision judgment of the civil procedure legal system is not within the scope of the judge's decision. A formal court judge ruling should have a higher standing than the arbitration decision, since the arbitral decision is merely a decision taken by arbitrator (arbiter). A civil procedure law providing legal remedy against the Court's first court judgment, by appeal to cassation. In the decision of the Cassation as the final legal remedy which has had binding legal force (inkraht van gewijsde), it is still given extraordinary remedies through review, while in Law Number 30 Year 1999 on Arbitration and Alternative Dispute Settlement, the extraordinary law. Law Number 30 Year 1999 on Arbitration and Alternative Dispute Resolution Article 70 has actually provided a loophole to file a cancellation of arbitration decision, that is, as stipulated in the provision.

The provisions concerning the existence of an arbitrage judgess oversight in deciding cases shall be regulated in view of the absolute nature of the arbitral decision, as well as the possibility of the existence of the subjects in consideration.

The above facts give rise to an imbalance to the principle of justice in the process of dispute resolution. According to Aristotle, law can only be established in relation to justice and justice must be understood in terms of equality ${ }^{2}$. Justice in an Islamic perspective is a universal and comprehensive benefit. The universality of justice in Islam encompasses all aspects of human life, both in the past, present and future ${ }^{3}$.

2 Carl Joachim Friedrich, Filsafat Hukum Perspektif Historis, (Bandung : Nuansa dan Nusamedia, 2004), page 24

3 Apridar, Keadilan dalam Islam, http://aceh.tribunnews. com/2014/02/07/keadilan-dalam-islam, accessed on 10 November 2015 
This means that in the Islamic perspective, the arbitrate decision must be based on a universal and comprehensive benefit, so as to provide room for those who object to the decision to make a formal remedy.

Driven by the phenomenon, the author was interested to make a research entitled The Absolute Properties of Arbitration Decision in Business Dispute Settlement Based on Law No. 30 of 1999 on Arbitration and Alternative Dispute Resolution in the perspective of Justice Theory.

Based on the phenomenon regarding the settlement of business settled through the arbitration institution, then the issues raised can be formulated as follows: What are the disadvantages of exercising the authority of the arbitration body over the absolute nature of the arbitral decision in the settlement of the current business dispute. And what is the Absolute Characteristic of the Arbitration Decision in Business Dispute Settlement Based on Law Number 30 of 1999 on Arbitration and Alternative Dispute Resolution in the perspective of Theory of Justice.

\section{B. DISCUSSION}

1. Disadvantages of exercising the authority of the arbitration body over the absolute nature of the arbitral decision in the settlement of the current business dispute

According to Lawrence Meir Friedman the success or failure of law enforcement depends on: Substance Law, Legal Structure/Legal Institution and Legal Culture. Here the writer explored the weaknesses of the implementation of the authority of the arbitration institution against the absolute nature of the arbitration decision in the current business settlement.

\section{Weakness in Substance Law}

The juridical basis in dispute settlement through arbitration institution can be reviewed from the provisions of Article 3 of Law Number 30 Year 1999 on Arbitration and Alternative Dispute Settlement.

Referring to the provision of Article 3 of Law Number 30 Year 1999 concerning Arbitration and Alternative Dispute Settlement mentioned above, the district court is declared not authorized to adjudicate the dispute of the parties which have been bound by the arbitration agreement. The jurisdiction of the district court is taken over by an arbitration body under the arbitration agreement. Regarding this matter has been confirmed in the provision of Article 4 of Law Number 30 Year 1999 About Arbitration and Alternative Dispute Settlement.

The arbitration agreement is basically an asseccoir agreement, it is a follow-up agreement (agreement under which the principal agreement). The principal agreement in the arbitration agreement is an agreement of its scope is an agreement in the field of trade (business). It can be known from the provisions of Article 5 paragraph (1) of Law Number 30 Year 1999 concerning Arbitration and Alternative Dispute Settlement stating that Disputes that can be resolved through arbitration are merely disputes in the field of trade and on rights which, by law and by law fully controlled by the parties to the dispute. Such activities include:
1. Commerce
2. Banking
3. Finance
4. Investment
5. Industry
6. Intellectual property rights

In view of the above-mentioned principles, the arbitration agreement made by the parties constituting an asseccoir agreement shall be in conformity with the principal agreement. The facts show that, although the arbitration agreement is asseccoir, but it is not necessarily deleted even if the agreement is substantially removed. This can be seen from the provisions of Article 10 of Law Number 30 Year 1999 on Arbitration and Alternative Dispute Settlement.

The next arbitrator shall issue an arbitral decision. Affirmed in Article 55 of Law Number 30 Year 1999 concerning Arbitration and Alternative Dispute Resolution that if the dispute is over, the examination shall immediately be closed and stipulated on the day of the hearing to speak the arbitral decision.

According to the provisions of Article 54 paragraph (2) of Law No. 30 of 1999 on Arbitration and Alternative Dispute Resolution, arbitral rulings are not signed by one of the arbitrators due to 
illness or death do not affect the validity of the decision. ${ }^{4}$

The arbitral decision is final. This is affirmed in the provision of Article 60 of Law Number 30 Year 1999 concerning Arbitration and Alternative of Settlement of Dispute stating that the decision of arbitration is final and has a permanent legal force and binds the parties. The juridical consequences of the final and binding arbitral decision, in the elucidation of Article 60 of Law Number 30 Year 1999 concerning Arbitration and Alternative Dispute Settlement, it is explained that the arbitral decision is final and therefore cannot be appealed, appealed or reviewed.

\section{Weakness in the Structure of the Law}

The structure of the legal system, according to Friedman, consists of an element of the size and size of the courts, its jurisdiction (including the type of case with which they are authorized to examine), and the court's appeal proceedings.

An arbitration institution with absolute authority can be seen in the provisions of Article 2 junctis Article 3 and Article 4 of Law Number 30 Year 1999 concerning Arbitration and Alternative Dispute Settlement. Article 2 of Law Number 30 Year 1999 concern on Arbitration and Alternative Dispute Settlement.

Under the provisions of Article 2 of Law Number 30 Year 1999 concerning Arbitration and Alternative Dispute Settlement above, it indicates that dispute settlement or disagreement between the parties in a certain legal relationship shall be the authority of the arbitration institution-if it has been agreed in an arbitration agreement. The authority of arbitration institutions in resolving disputes is reinforced by the provisions of Article 3 of Law Number 30 Year 1999 concerning Arbitration and Alternative Dispute Settlement states:

The District Court is not authorized to adjudicate disputes of the parties that have been bound by the arbitration agreement.

Article 3 of Law Number 30 Year 1999 concerning Arbitration and Alternative Dispute Settlement above expressly excludes the authority of the District Court to adjudicate disputes of

\footnotetext{
See article 57 dan 58, Article 60 and 70 UU no 30 year 1999
}

parties that have been bound by the arbitration agreement, so that the dispute resolution authority is granted to the arbitration body.

The authority of the arbitration institution in handling dispute settlement is also affirmed in the provisions of Article 4 paragraph (1) of Law Number 30 Year 1999 concerning Arbitration and Alternative Dispute Settlement.

The basis right or legal basis for the absolute authority of a limited arbitration institution in the settlement of disputes is in the field of trade, in accordance with the provisions of Article 3 is the existence of an arbitration agreement. The arbitration agreement, thus, constitutes a basis for the exercise of the absolute authority of the arbitral institution.

In the development in Indonesia, in the arbitration dispute settlement, there is emerged a controversial flow, namely the Supreme Court Decision Number 1851 K/Pdt/1984. The Supreme Court Decision Number 1851.K/Pdt/1984 is a split contrary to the flow of pakta sunt servanda. Principally stating that even though there is an arbitration clause in the agreement of the parties, even though there is a dispute from one of the third parties to be brought to the District Court, but the District Court still declared itself authorized and the Supreme Court justified. The reason given is because the parties are not serious (the term of the District Court concerned: "in the hearts of the parties there is no intention to use arbitration"). ${ }^{5}$

The nature of the cancellation of a new agreement can be proven if there is a lawsuit filed by either party to the judiciary. Based on Indonesia's positive law the jurisdiction of justice is in the Supreme Court. This can be seen in the provisions of Chapter IX Judicial Authority Article 24 of the 1945 Constitution of the State of the Republic of Indonesia.

Based on the constitution of the Republic of Indonesia, the Supreme Court holds an independent judicial power to administer the judiciary to enforce the law and justice with the lower courts within the general judiciary, the jurisdiction of the judiciary, the military court environment, the administrative court of the state and the Constitutional Court.

5 Munir Fuadi, Alternatif Penyelesaian Sengketa Bisnis, (Bandung: Citra Aditya Bhakti, 2000), page 122 
Implementation of judicial power owned by the Supreme Court is reflected in the Law of the Republic of Indonesia Number 14 Year 1985 regarding the Supreme Court as amended lastly by Law of the Republic of Indonesia Number 3 Year 2009 Concerning the Second Amendment to Law Number 14 Year 1985 Concerning the Supreme Court. Article 1 of the Law of the Republic of Indonesia Number 14 Year 1985 Concerning the Supreme Court as amended by the Law of the Republic of Indonesia Number 3 Year 2009 Concerning the Second Amendment to Law Number 14 Year 1985 The Supreme Court declares that the Supreme Court is State Higher Institution as intended in the Decree of the People's Consultative Assembly of the Republic of Indonesia Number III / MPR / 1978.

The provisions of Article 2 of the Law of the Republic of Indonesia Number 14 of 1985 concerning the Supreme Court as amended lastly by the Law of the Republic of Indonesia Number 3 of 2009 concerning the Second Amendment to Law Number 14 Year 1985 concerning the Supreme Court.

Based on the above provision, it can be concluded that the Supreme Court is the highest state court as the holder of judicial power in Indonesia. This is in line with the provisions of Article 24 paragraph (2) of the 1945 Constitution of the State of the Republic of Indonesia.

One of the judicial institutions under the auspices of the Supreme Court is the General Courts. According to the provisions of Article 2 of the Law of the Republic of Indonesia Number 2 of 1986 concerning General Courts as amended the latest by Law of the Republic of Indonesia Number 49 Year 2009 Concerning the Second Amendment to Law Number 2 Year 1986 Concerning the General Courts.

Based on the above provisions, it can be understood that within the scope of judicial power, there are several other courts outside the general court. ${ }^{6}$

General Elucidation of Law of the Republic of Indonesia Number 2 Year 1986 regarding General Court as lastly amended by Law of the Republic of Indonesia Number 49 Year

\footnotetext{
6 See UU no 49 year 2009 concerning the second changes
} on UU no 2 year 1986 on general court
2009 Concerning Second Amendment to Law Number 2 Year 1986 concerning General Court affirms that:

The Judicial Power within the General Courts of the Act is administered by the District Court and the Court of Appeals culminating in the Supreme Court, in accordance with the principles prescribed by Law Number 14 Year 1970 on Judicial Power (as already amended by Law Number 48 of 2009 on Judicial Power).

It is also reinforced by the provision of Article 10 of Law of the Republic of Indonesia Number 48 Year 2009 on Judicial Power which affirms:

(1) The court is prohibited from refusing to examine, hear, and decide upon a case filed under the pretext that the law is absent or less clear, but obligatory to examine and prosecute.

(2) The provisions referred to in paragraph (1) shall not close the settlement of civil cases in a peaceful manner.

The provisions of Article 10 paragraph (1) above indicate the strong authority possessed by the courts as the executor of the judicial power, so the court is prohibited from refusing to examine, hear and decide on a case filed under the pretext that the law is absent or less clear. The court is obliged to examine and adjudicate every case it submits.

\section{Weakness in Legal Culture}

General explanation of Law Number 30 Year 1999 Concerning Arbitration and Alternative of Settlement of Dispute also states that in general arbitration institution has advantages compared with judicial institution. The advantages include:

1. Secured confidentiality of parties' disputes

2. Avoidable delays caused by procedural and administrative matters

3. The parties may choose an arbitrator who, by his or her belief, has sufficient knowledge, experience and background on the disputed, honest and fair matter;

4. The parties may decide the choice of law to resolve the matter and the process and place of arbitration; and 
5. The arbitral decision shall be a decision binding on the parties and by a simple or straightforward procedure.

On the basis of the foregoing considerations, the arbitration shall be one of the main options in the dispute resolution of the parties. In such a position, the role of an arbiter or arbitral tribunal becomes very important.

At the implementation level, an arbitrator must be able to maintain an inner attitude and behavior as a responsible arbiter.

Arbitrators authorized by the parties pursuant to Article 4 paragraph (1) of Law No. 30 of 1999 on Arbitration and Alternative Dispute Resolution, ie in the event that the parties have agreed that the dispute between them shall be settled by arbitration and the parties have authorized, then since that time the arbitrator must be able to be objective. Objective attitude is realized in 2 (two) forms, namely:

\section{Inner attitude}

The inner attitude is manifested in a high self-awareness to:

\section{a. a strong independent (free) mentality}

Being mentally independent here means that an arbitrator by virtue of his authority and status protected by law is granted a freedom which cannot be interfered by anyone in conducting an examination in the course of a dispute settlement of the parties which under the arbitration agreement has agreed to submit the settlement to an arbitrator or arbitral tribunal.

\section{b. objective in the analysis}

The objective in the analysis here means that the considerations to be taken by the arbitrator or arbitral tribunal are strictly based on the experience and capabilities it possesses in relation to trade disputes. In relation, it is reasonable that an arbitrator pursuant to Article 12 paragraph (1) subparagraph e of Law Number 30 Year 1999 Concerning Arbitration and Alternative Dispute Settlement must have experience and actively control in his field for at least 15 years.

\section{c. impartial (neutral)}

Neutral here means that an arbitrator or an arbitral tribunal has the integrity to be fair and impartial to one of the parties to the dispute. Arbitrators or arbitration court must be able to remove doubts in the parties concerned.

\section{Behavior}

Behavior here means that an arbitrator or an arbitral tribunal can act wisely by prioritizing peace efforts. Arbitrators or arbitral tribunals should optimally seek points of intersection during the arbitration proceedings; seriously explore, live, observe all evidences and statements of the parties.

The professional principle in analyzing cases as a whole, rational and logical is the main capital for an arbitrator or arbitral tribunal in carrying out its duties and authority by holding the principle of neutrality (neither the beneficiary nor the injured), accurately determining the core of the problem and resolve the dispute by producing a fair Arbitration Ruling.

The fact shows that it is difficult to find an arbitrator or an arbitral panel that can meet the expectations of both parties. This is because an arbitrator or an arbitral tribunal is an ordinary human being who under certain conditions and situations is difficult to realize the attitude of objectivity and neutrality in deciding a dispute between the parties.

\section{Absolute Properties of Arbitration Ruling in Business Dispute Settlement Based on Law No. 30 of 1999 on Arbitration and Alternative Dispute Resolution in the perspective of Justice Theory}

Aristotle's views on justice can be found in his work nichomachean ethics, politics, and rethoric. More specifically, in the book of nicomachean ethics, the book is entirely devoted to justice, which, according to Aristotle's general philosophy, should be regarded as the core of his legal philosophy, "because law can only be established in relation to justice." The most important thing from his view is the notion that justice must be understood in the sense of equality. However, Aristotle makes an important distinction between numerical equality and proportional

$7 \quad$ Carl Joachim Friedrich, Filsafat Hukum Perspektif Historis, (Bandung : Nuansa dan Nusamedia, 2004), page 24 
equality. Numerical similarity equates every human being as a unit. This is what we now understand about commonality and what we mean when we say that all citizens are equal before the law. Proportional equality gives each person what he deserves in accordance with his abilities, accomplishments, and so forth.

Aristotle presented much controversy and debate about justice. Furthermore, Aristotle distinguished justice into:

1) Distributive justice

Distributive justice is applicable in public law

2) Corrective justice.

Corrective Justice is applicable in civil and criminal law

Distributive and corrective justices are equally susceptible to the problem of equality and can only be understood in their framework. In the area of distributive justice, the important thing is that the equal pay is given for equal achievement. In the second, the problem is that inequality caused by, for example, a breach of agreement, is corrected and eliminated.

The concept of justice in Islam has been widely taught in the Qur'an and in al-Hadith, there are many verses and traditions of the Prophet which explain the necessity of the Judge to be fair, but all the teachings of justice in al-qur'an essence has been practiced and exemplified by Rosululloh SAW in handling every case of law and justice requested to the Prophet Muhammad as one of the words of Allah SWT in AI-Quran Surah AI-Baqarah Surah 213:

Meaning:

Man is one people. (after a dispute arose), God sent the prophets, as a warner, and Allah sent down with them the true Book, to make decisions among men about the matter which they disputed. There is no dispute concerning the Book but the one who was sent to them the Book, that is, after coming to them the real testimonies, out of envy among themselves. So Allah guides those who believe in the truth about what they disagree with His will. And Allah always gives the guidance of His will to a straight path (QS AI Baqaroh: 213)

The outcome of the arbitration shall be an arbitration decision pursuant to the provisions of
Article 60 of Law Number 30 Year 1999 concerning Arbitration and Alternative Dispute Settlement, Arbitral decision is final and has a permanent legal force and binds the parties. Based on the explanation of Article 60 of Law Number 30 Year 1999 concerning Arbitration and Alternative Dispute Settlement, Arbitral decision is final and therefore cannot be submitted an appeal, cassation or review. The provision of Article 60 of Law Number 30 Year 1999 concerning Arbitration and Alternative Dispute Settlement has closed the opportunity for one of the parties who is not satisfied with the arbitration decision to take a legal action.

With respect to the arbitration decision, there is only one legal remedy which can be performed by the dissatisfy party with the arbitration decision, namely the cancellation as regulated in Article 70 of Law Number 30 Year 1999 on Arbitration and Alternative Dispute Settlement.

Arbitrators or arbitral tribunal in taking arbitral decision, by law is given two options, namely the decision based on the rules of material law or judgment based on the principle of justice and the principle of propriety. In the arbitrator or arbitral tribunal position the authority to decide upon the basis of justice and propriety, the provisions of the legislation may be excluded by arbitrators or arbitral tribunals, unless the provision of enforceable legal provisions (dwingende rege/s) shall be applied, arbiters or arbitral tribunal shall be subject to the rules the law.

The arbitral decision judging from the basic values of justice can be traced through the approach of the theory of justice as it evolves so far. The theory of justice is born out of the science of philosophy and as a root that grows and develops as the human consciousness develops. The theory of justice can be regarded as a legal crown that has been maintained since Socretes to Francois Geny as part of the theory of natural law. Natural Law Theory prioritizes "the search for justice" 8 . The theory of equity in its development also has many variations depending on the point of view and background of the discipline of the experts who put it forward.

8 Theo Huijbers, Filsafat Hukum dalam lintasan sejarah, cet VIII, (Yogyakarta: Kanisius, 1995), page. 196 
Justice according to Aristotle is the same, in the sense that everyone has the same rights, so justice is defined as a commonality. The similarity in the concept of justice according to Aristotle can be divided into two, namely:

\section{a. Numerical Similarities}

The numerical similarity in Aristotle's opinion is to equate each person as a unit with the same rights and duties without being influenced by the background or entity that is in it. This numerical commonality applies to everyone. This embodiment of numerical equality can be expressed in a simple understanding, ie when it comes to citizens, then according to numerical parity, all citizens are equal before the law. In such a position, the position, rank, title of social status does not affect the equal rights and obligations of loyal people before the law.

\section{b. Proportional Equality}

The same proportionality in Aristotle's view is to equate everyone (person), give each person what he deserves in accordance with his abilities, accomplishments, and so forth. Proportional justice places emphasis on the position, position of those who should have rights on the ground, so it would be unfair if for example a public official should have more security facilities on duty, treated equally with ordinary citizens.

Judging from its scope, Aristotle divided justice into two, namely:

\section{a. Distributive justice}

Distributive justice is applicable in public law. Distributive justice according to Aristotle focuses on distribution, honor, wealth, and other goods that can be found in society. By putting aside the mathematical "proof", it is clear that what Aristotle thought was the distribution of wealth and other valuables based on the values prevailing among the citizens. Fair distribution may be an appropriate distribution of good values, the values for the people. ${ }^{9}$

b. Corrective Justice.

Corrective Justice is applicable in civil and criminal law. Corrective Justice focuses on rectifying something wrong. If a violation is violated or an error is committed, then corrective justice seeks to provide adequate compensation to the injured party; if a crime has been committed, then

9 Ibid, page 25 the appropriate punishment should be given to the perpetrator. However, injustice will result in disruption of established or established "equality". Corrective Justice is in charge of rebuilding the equality. From this description it appears that corrective justice is the territory of justice while distributive justice is the field of government. ${ }^{10}$

Regardless of the controversy over Aristotle's thinking, corrective justice can be used as a mean of analysis to judge the arbitral decision whether it has embodied the value of justice as proposed by Aristotle. The arbitral decision arises from a dispute between the parties in the field of trade which the parties then agree to settle by arbitration. According to the conception of numerical justice, the parties have a common position to seek justice and obtain justice. This means that dispute settlement through arbitration must be based on the agreement of the parties in their equal rights and position. According to the conception of proportional justice, the parties in their positions as the subject of the agreement, it will be seen the position of each party. For example in a lease agreement, proportionally it must be known to the leasing party and the party hiring, the rights and obligations of each party. Based on these rights and obligations, it will be possible to apply proportional justice in an arbitral decision.

Arbitrators or arbitral tribunals based on the concept of corrective justice should assess the issues on which the dispute is concerned. Arbitrator or arbitral tribunal after knowing the disputed items, with the ability and knowledge it possesses will make corrections to the violations that occur and provide the fairest decision based on the correction result.

Arbiter or arbitral tribunal with the authority possessed under the provisions of Article 3 of Law Number 30 Year 1999 concerning Arbitration and Alternative Dispute Settlement shall be given absolute authority to take an arbitration decision as regulated in the provisions of Article 60 of Law Number 30 Year 1999 concerning Arbitration and Alternative Settlement of Dispute without anybody being able to make corrections to the decision because the arbitral decision is final and has a permanent legal force and binds

10 Ibid. 
the parties. The decision of the arbitration shall be the final verdict and shall therefore not be appealed, cassation or review.

This final and legally binding arbitral decision, if associated with Aristotle's corrective theory of justice, does not at all reflect the basic value of justice. This is indicated by not giving an opportunity for another party whose position is higher to correct the decision, whereas in the judicial system, the court as an ordinary court having legal status (legal statue) and legal authority (legal authority/legal power), verdict the panel of judges can still be corrected through the usual remedies (appeals, appeals) and extraordinary remedies (judicial review).

Corrective Justice which is based on the basic conception of the correction of a mistake that caused the birth of injustice, in the context of subordinate relations, then there should be an institution authorized to make corrections on the arbitral decision such as review. In this situation the absolute nature of the arbitral decision needs to be reconstructed based on the concept of justice according to Aristoteles.

The birth of awareness of perfect justice belongs only to God Almighty, encouraging awareness that the decision taken by the courts is unlikely to provide fairness. Based on these assumptions, efforts to make corrections to court decisions at the first level are given up to the appellate level of the Supreme Court. The judiciary as an official judicial forum, its verdict can still be a legal effort although it has been final and has a permanent legal force (inkraht van gewisjde). The same thing should be applied to the arbitral decision which is an extra-judicial institution.

\section{CONCLUSION}

Under the provisions of Article 2 of Law Number 30 Year 1999 concerning Arbitration and Alternative Settlement of Disputes, it indicates that dispute settlement or disagreement between the parties in a certain legal relationship shall be the authority of the arbitration institution-if it has been agreed in an arbitration agreement. The authority of the arbitration institution in resolving the dispute is reinforced by the provisions of Article 3 of Law Number 30
Year 1999 on Arbitration and Alternative Dispute Settlement. According to Lawrence Meir Friedman the success or failure of law enforcement depends on: Substance Law, Legal Structure/Legal Institution and Legal Culture. The disadvantages of the exercise of the arbitration authority's authority over the absolute nature of the arbitral decision in the settlement of the business are currently in the substance, structure and legal framework, so there is an amendment to Law no 30 of 1999 on Arbitration and Alternative Dispute Resolution.

This final and legally binding arbitral decision, if associated with Aristotle's corrective theory of justice, does not at all reflect the basic value of justice. This is indicated by not giving an opportunity for another party whose position is higher to correct the decision, whereas in the judicial system, the court as an ordinary court having legal status (legal statue) and legal authority (legal authority / legal power), verdict the panel of judges can still be corrected through the usual remedies (appeals, appeals) and extraordinary remedies (judicial review).

The need for awareness and assertiveness of the parties or representatives in entering into a contract of agreement should contain clauses on future dispute resolution in case of a dispute shall be settled by way of a direct settlement to the litigation domain or will avoid the litigation domain. In the case of non-litigation settlement areas, clarity and assertion of the parties shall be settled through certain arbitration institutions such as BANI or simply by means of consensus and mediation.

The arbitration institution may, however, have absolute authority to examine and resolve the dispute of the parties in a particular legal relationship, but such authority only exists if the parties agree that a dispute resolution that will arise or that has arisen is resolved through an arbitration institution evidenced by an arbitration agreement form pactum de compromittendo or acta de compromise. Without an arbitration agreement, the arbitration body shall have no authority to resolve the dispute. 


\section{BIBLIOGRAPHY}

Carl Joachim Friedrich. 2004. Filsafat Hukum Perspektif Historis, Bandung : Nuansa dan Nusamedia. Munir Fuadi. 2000. Alternatif Penyelesaian Sengketa Bisnis, Bandung: Citra Aditya Bhakti.

Peter Mahmud Marzuki,Penelitian Hukum, cet 2,Jakarta: Kencana, 2008

Soerjono Soekanto dan Sri Mamudji. 2010. Penelitian Hukum Normatif suatu Tinjauan Singkat, Jakarta: Raja Grafindo Persada

Subekti. 2004. Aneka Perjanjian, Bandung : Alumni Bandung.

Theo Huijbers. 1995. Filsafat Hukum dalam lintasan sejarah, cet VIII, Yogyakarta: Kanisius,

Undang-Undang no 30 tahun 1999 tentang Arbitrase dan Alternatif Penyelesaian Sengketa Hukum

Undang-Undang no 49 tahun 2009 tentang Perubahan Kedua Atas Undang-Undang no 2 tahun 1986 tentang peradilan Umum 